\title{
LAS ARTES EFÍMERAS AL SERVICIO DE LA PROPAGANDA DE LA CASA DUCAL DE MEDINA SIDONIA (1515-1639)
} \author{
(1515-1639) \\ FERNANDO CRUZ-IsIDORO \\ Universidad de Sevilla, España \\ cruzisidoro@us.es
}

THE EPHEMERAL ARTS TO THE SERVICE OF THE PROPAGANDA OF THE DUKES OF MEDINA SIDONIA

Se analiza la actividad constructiva efímera de los Pérez de Guzmán en la capital de su Estado, Sanlúcar de Barrameda, entre los años 1515 y 1639. Se aportan datos sobre los túmulos levantados para las honras de la familia y de la Corona, los anuales Monumentos del Jueves Santo, y las fiestas de estreno de varias fundaciones religiosas patronadas por la Casa.

Palabras clave: Arquitectura efímera. Túmulo. Monumento del Jueves Santo. Fiestas de estreno. Casa ducal de Medina Sidonia.

This article documents the ephemeral constructive activity of them Pérez de Guzmán in the capital of their State, Sanlúcar de Barrameda, between the years 1515 and 1639, with the ephemeral sepulchral monuments in honors of the family and the Crown; the building of the Monuments of the Holy Thursday; and the feasts of consecration of several churches sponsored by them.

Key words: Architecture and decoration ephemeral. Dukes of Medina Sidonia. Sanlúcar de Barrameda.

La investigación documental efectuada en las dos últimas décadas sobre el patronazgo artístico de la Casa ducal de Medina Sidonia, pone de evidencia la creación de una imagen corporativa, casi de empresa, de cara a los vasallos de sus amplias posesiones territoriales y demás individuos que recalaban en ellas o participaban de sus fundaciones, que si surge de forma espontánea en los siglos XIV y XV, en el XVI y primera mitad del XVII adquirió forma programada, una vez tomada conciencia de su importancia en la zona, alentada por cronistas como Pedro de Medina y Pedro Barrantes Maldonado con sus respectivas historias sobre los miembros de la familia, y más tarde desarrollada por aduladores como el 
dominico fray Pedro Beltrán en su Charidad Guzmana (1612) con respecto al VII duque Don Alonso, o el poeta Pedro de Espinosa, que también lo exalta y al VIII duque Don Manuel. Sin olvidar a auténticos iconólogos de la Casa, como su capellán mayor Diego López de Soria, que ideó una eficaz programación de halago a los Pérez de Guzmán para el sanluqueño Santuario de Ntra. Sra. de la Caridad, panteón de los VII duques, plasmada por el pintor ducal Francisco Juanete, que nos ha dejado una interesantísima representación barroca de las grandezas de la Casa en el singular cuadro de altar de la Genealogía de los Guzmanes, emparejada, al mismo nivel de importancia, con la Genealogía de Cristo, lo que no podía ser un mensaje más claro ${ }^{1}$. En ese mundo de ideas, que surge al calor del fecundo patronazgo artístico en su amplio estado territorial y centrado en su capital, Sanlúcar de Barrameda, las artes efímeras se pondrán, igualmente, a su servicio, para completar la visión, pues aunque, por esencia, esas arquitecturas o fiestas duran horas o a lo sumo días, sin lugar a dudas dejaron una huella indeleble en los actores secundarios de ese teatro que fue la vida del Antiguo Régimen, que la documentación de archivo sólo permite reconstruir sucintamente, al señalarnos artífices, materiales, coste y, a veces, muy pocas, el reflejo de su apariencia, porque nunca alcanzaremos el grado de impacto que produjeron al vivirlas en primera persona.

\section{LA FINANCIACIÓN}

Para el caso sanluqueño, los montajes efímeros y fiestas patrocinadas o vinculadas con la Casa fueron costeados por la misma, saliendo abundantemente los maravedíes de las arcas ducales. Aunque también contribuyeron, en menor medida y según las circunstancias, las instituciones dependientes, como la municipal, intermediaria civil con los vasallos y estantes en la ciudad, como los numerosos comerciantes de distintas nacionalidades a los que había que impactar y que daban a la urbe su aspecto cosmopolita, y las eclesiásticas, con las diversas religiones que componían el entramado de esta ciudad-convento, dormitorio de frailes y monjas en tránsito hacia las Indias, y lugar donde los muchos presbíteros aduladores que pululaban por sus calles solicitaban una capellanía, que no dejaban de ser fieles mediadores de los intereses de los Guzmanes en el plano religioso y laico.

La dinámica seguida por el Cabildo sanluqueño era repetitiva. Los regidores se reunían presididos por el corregidor para tratar el fatal evento, adoptar la postura a seguir y nombrar una diputación de uno o varios regidores que de forma más efectiva propusiese qué hacer, tras comprobar lo efectuado en análogas

${ }^{1}$ CRUZ ISIDORO, Fernando: "Un cuadro de altar de trasfondo ideológico: "la Genealogía de los Guzmanes", del pintor barroco Francisco Juanete (1612)". Archivo Español de Arte $\mathrm{n}^{\circ}$ LXXVIII., 2005, pp. 427-434. 
circunstancias y el coste para las arcas municipales, postura que volvía al cabildo para ser, normalmente, ratificada, tras lo cual se ponían a disposición del señor de la villa, asumiendo parte de los gastos, o bien se tomaba una actitud más participativa, realizando parte de las estructuras o festejos, para lo que adquirían los materiales convenientes y se contrataba el personal adecuado. Por su parte, el señor o señora, delegaba en persona o personas de su confianza su ejecución, con la participación del maestro mayor de obras ducales, carpinteros y otros operarios, como veremos a continuación, ordenando las libranzas en alguno de sus fieles ejecutores y receptores de rentas, como el de la Aduana, o en el tesorero, que luego exhibían la correspondiente carta de pago para hacerla buena a la hora de tomarles cuentas el contador mayor ducal "y oficiales de mis libros que os lo resçiban y pasen en quenta"2.

En cuanto a los Monumentos efímeros para la ostentación del Jueves Santo, que se levantaron en la parroquia mayor de Ntra. Sra. de la O y en los conventos dominicos de Santo Domingo y de Madre de Dios, el coste del diseño, materiales, ensamblaje y desmontaje corrió siempre a cargo de la contaduría ducal, lo mismo que el de las fiestas de estreno de los edificios religiosos que levantaron los Guzmanes.

\section{MATERIALES Y ARTÍFICES}

Dado su carácter efímero, los materiales empleados en estas estructuras eran frágiles, y por tanto ninguno o muy pocos de sus elementos han llegado a la actualidad, lo que es lógico cuando la fiesta a celebrar era puntual, pero también cuando algunas y sus correspondientes adornos fuesen cíclicos, como los Monumentos Pascuales, puesto que el desgaste de su montaje y desmontaje los hacía poco perdurables, reciclándose constantemente sus piezas, para variar las formas, motivando al final su pérdida. Y no siempre esos componentes fueron baratos pues, como veremos, los textiles y su teñido para los túmulos funerarios, solían ser costosos. La madera empleada, de tamaños diferentes según recoge la propia documentación, que podemos calibrar gracias a las medidas fijadas por las Ordenanzas de Sevilla, fue uno de los principales componentes y de las partidas más sustanciosas. Sobre ella van a trabajar carpinteros y algunas veces escultores para darle forma y, los pintores, que transformarán su aspecto mutándolo a una textura matérica diferente, como el mármol, el bronce o incluso la carne. Las órdenes y cartas de pago y las diferentes anotaciones de la data, vistas y revistas por los contadores ducales, recogen los nombres de esos artífices y el coste de su

${ }^{2}$ Archivo Fundación Casa Medina Sidonia (AFCMS) leg. 2.497. Sobre las exequias de los Guzmanes en Huelva, véase LARA RÓDENAS, Manuel José de: "El Poder y la Muerte. Mandatos de lutos y gobierno de los sentimientos en la Huelva del Barroco", Aestuaria. Revista de Investigación, 1, 1992, pp. 49-65 
trabajo, que hemos podido comprobar eran los mismos que intervenían en otras obras de carpintería sufragadas por la Casa en castillos y edificios dependientes. Se repite constantemente la participación del maestro carpintero de la Casa ducal, que contrataba individualmente cada una de las intervenciones, y aunque en la documentación aportada nunca se señala la traza, condiciones o dirección de la estructura efímera o el montaje, es de suponer que corriesen a cargo del Maestro mayor de obras ducales, figura cuya existencia hemos constatado desde, al menos, 1495, con el albañil Juan de Acevedo, documentando lo fueron, en el periodo tratado, Francisco Rodríguez (1565), Juan de Castilla (1603-1606), Álvaro de Quenda (1606-1609), Bartolomé Rodríguez (1610-1617), Antón Sánchez (1617-1624), Francisco de Valenzuela (1624-1632), Martín Rodríguez de Castro (ca.1633-1637) y Pedro de Liébana $(1653)^{3}$. Posiblemente, también trazaron los montajes de los Triunfos Eucarísticos levantados el Jueves Santo en la parroquia y en el convento de Santo Domingo, dibujos que bien pudieron servir para más de un año y facilitarían su trabajo al carpintero ducal, que casi nunca coincide con los operarios que luego los desmontan, mientras que en el convento de dominicas de Madre de Dios, su estructura monumental era perdurable, y se ensambló la misma durante años.

\section{EL TRIUNFO SOBRE LA MUERTE: LAS HONRAS FÚNEBRES POR LOS DUQUES, FAMILIARES Y MONARCAS}

Como ocurría y todavía ocurre con las honras de los monarcas y altas jerarquías eclesiásticas, las grandes familias nobiliarias levantaron en la España moderna, a un nivel acorde con sus posesiones señoriales, distinción, funciones cortesanas y medios económicos, similares monumentos efímeros, símbolos del Triunfo de la Fama y el Linaje sobre la Muerte, aderezados con toda la liturgia y ceremonial que se acostumbraba. Sus diseños intentaban parecerse, a menor escala, a los contemplados, en alguna gran urbe cercana, para honrar al rey o jerarca eclesiástico fallecido y cuyo recuerdo aún latía en sus mentes, pero las condiciones económicas y la falta del personal apropiado determinaron las más de las veces el uso de sencillos modelos y quizás estructuras conservadas parcialmente que facilitaban el proyecto y montaje final, consiguiendo cambiar cada vez su fisonomía gracias al aditamento de adornos y luminarias. Desde siempre, o al menos desde época prehistórica, como se constata en estelas funerarias de la etapa geométrica de la cultura tartésica del Bronce final, del SO peninsular, como la cordobesa de Ategua, y por los hallazgos arqueológicos de los ustrinium o depósitos de ceniza, el túmulo consistía en una funcional estructura de

${ }^{3}$ CRUZ ISIDORO, Fernando: El convento sanluqueño de Capuchinos. Arte e Historia de una fundación Guzmana. Sanlúcar de Barrameda: ASEHA, 2002, pp. 46-49. 
troncos apilados de forma cuadrangular decreciente, donde se colocaba el cadáver para su exposición previa a la incineración, dando lugar a esa forma finisecular que se ha mantenido hasta hoy, la sencilla de cajón o cajones rectangular y decreciente. Desde esa forma elemental, el desbordante diseño dará lugar a estructuras centradas de planta rectangular, circular o cruciforme, de uno o varios pisos, con tendencia a alcanzar cierta altura, las de enjundia organizadas por columnas u otro tipo de soporte según la época, remedo de la arquitectura de obra, e incluso a veces con cubrición abovedada, trasunto celestial, y donde la iconografía religiosa, bien en estatuaria o pintada, la heráldica de la Casa y los lenguajes jeroglíficos, como los símbolos personales, entonados en la propia estructura o formando parte de cartones, lienzos, tapices, gallardetes o cualquier otro elemento textil adherido, daban la nota intelectual del mensaje simbólico que se pretendía desarrollar, junto a elementos geométricos afines, como pirámides u otras formas de remate que elevaban la estructura y la mirada hasta enlazarla con la divinidad, sin faltar efectos luminosos apropiados al evento, como la abundante candelería y recipientes para la quema de productos odoríferos, con todo lo cual se conseguía crear una sensación sobrenatural, que escapaba a la realidad cotidiana. Podemos hacernos idea de la forma de amortajar a los duques, por la representación de Rodericus Guzmán en el citado cuadro de altar de la Genealogía de los Guzmanes, y de los escudos que escoltaban los túmulos, a veces con tenantes, por los que rematan el retablo mayor del Santuario de la Caridad, con la heráldica de los Guzmanes y Mendozas.

Cuando las estructuras se diseñaban para ser conservadas y minimizar los costes, se adquirían unos elementos que se utilizaban en todas las ocasiones, como se hizo en la institución creada por el VII duque en el Santuario de la Caridad, que contaba con una tumba y sus correspondientes luminarias para las defunciones de capellanes y otras personas de relevancia que allí se honraban. Don Alonso ordenó a su tesorero Fernando de Novela el 13 de diciembre de 1614 librar 60 reales al pintor Diego Bibanco "porque tiñó de negro los bancos, hacheros y tumba que está en la casa de Ntra. Sra. de la Caridad para las honras que allí se hicieron"4.

Pero esos acontecimientos requerían siempre gastos, pues había que vestir de luto a los criados, resultando onerosa la compra de telas a los mercaderes hispanos y flamencos que abundaban por sus calles, como ocurrió con la muerte del VI duque Don Juan Alonso el 26 de noviembre de 1558, cuyo cadáver fue depositado en el convento de Santo Domingo, empleándose 200 varas y una tercia de paño negro que vendió el mercader Juan de Rivera por 102.170 maravedíes $^{5}$.

En Sanlúcar, entre las fechas que barajamos en este estudio, se efectuaron mayoritariamente en la Parroquia mayor de Ntra. Sra. de la O, en el Barrio alto que

\footnotetext{
${ }^{4}$ AFCMS leg. 2.908.

${ }^{5}$ AFCMS leg. 2,546.
} 
actuaba como iglesia de Corte, inmediata al palacio de los Pérez de Guzmán al que se unía por medio de una tribuna o galería, y de forma puntual en las iglesias fundadas por los respectivos duques fallecidos, las más de las veces en las que les servirían de panteón, como el convento de dominicos de Santo Domingo, de clarisas franciscanas de Regina Coeli, el Santuario de Ntra. Sra. de la Caridad, o el convento de mercedarios descalzos de la Merced. Sin intentar hacer un catálogo, que ya realizo sucintamente el historiador Velázquez Gaztelu ${ }^{6}$, recogemos aquellas de interés de las que podemos aportar datos inéditos.

\subsection{Honras por la duquesa Doña Leonor de Zúñiga y Guzmán (+1515)}

Una de las primeras celebradas en Sanlúcar, de las que tenemos constancia documental, fueron por la segunda mujer del III duque Don Juan de Guzmán, Doña Leonor de Zúñiga y Guzmán, de la Casa de Béjar y su prima, por lo que sus relaciones se consideraron incestuosas hasta que fueron legalizadas por Roma con la correspondiente bula y posterior casamiento. Fue madre del V duque Don Alonso "el fatuo" y del VI Don Juan Alonso, desempeñando el gobierno de la Casa dos años, desde el fallecimiento en 1513 del IV duque Don Enrique, hijo del III duque y su primera mujer Isabel de Velasco, en la dura minoría de edad del suyo, que era deficiente, hasta su propia muerte en $1515^{7}$. En cabildo municipal de 5 de noviembre, presidido por el corregidor Francisco de Salcedo y con la asistencia de los regidores Juan Cordero, Alonso Peláez, Hernán Guillén, Luis de Bolaños, Andrés de Herrera, Francisco de Peralta, Hernán Sánchez Cordero, y del procurador Pedro de Segovia, "platicaron sus mercedes sobre las onrras que se deven hazer por la duquesa doña Leonor de Zúñiga, nuestra señora, que santa gloria aya", ordenando se hicieren "el sábado en la tarde de primero que viene, e el domingo de mañana, porque faziéndolo estos días avrá mucha gente en las dichas onrras". Peralta quedó encargado de su supervisión. Se realizaron en el desaparecido convento de San Francisco "el viejo".

${ }^{6}$ VELÁZQUEZ GAZTELU, Juan Pedro: Historia antigua y moderna de Sanlúcar de Barrameda. Año de 1760. Vol. II Estudio prelim. y transcrip. de Manuel Romero Tallafigo. Sanlúcar de Barrameda: A.S.E.H.A,1994, pp. 481-486.

7 VELÁZQUEZ GAZTELU, Juan Pedro: Catálogo de todas las personas ilustres y notables de esta ciudad de Sanlúcar de Barrameda. Año de 1760. Edi. y transcrip. de Fernando Cruz Isidoro. Sanlúcar de Barrameda: A.S.E.H.A., 1997, pp. 225-226, 228; ÁLVAREZ DE TOLEDO, Luisa: Casa Medina Sidonia, de Juan de Guzmán a Gaspar de Guzmán (14921664). Sanlúcar de Barrameda: Fundación Casa Medina Sidonia, 2008 (Notas Genealógicas $\mathrm{n}^{\circ} 2$ ), pp. 8-9, 13-14.

${ }^{8}$ Archivo Municipal de Sanlúcar de Barrameda (AMSB) leg. 4.702 fols. 117 vto, 118 y vto., 121. 


\subsection{Honras por el marqués de Gibraleón (+1559)}

Celebradas en la parroquial de Ntra. Sra. de la O por orden de su hermana, la condesa de Niebla Doña Leonor Manrique de Sotomayor, de la Casa de Ayamonte y Béjar, que dirigió la ducal con enorme efectividad en su viudedad, durante la minoría de edad de su hijo el VII duque Don Alonso, resultan de gran interés porque se conserva íntegra su contabilidad, con todos los descargos registrados en los libros de cuentas de Luis de Cabrera, "thesorero del duque, mi hijo, en los maravedís de su cargo". Recogemos íntegramente los pagos porque, aunque prolijos, pueden servirnos como ejemplarizantes para conocer en profundidad la huella documental, de porte económico, que suele dejar este tipo de estructuras, con anotaciones desde el 13 de abril al 26 de noviembre de 1559, que son las siguientes: 12 maravedíes "por subir setenta varas de paño a la recámara de los mercaderes, para el túmulo de las honras por el señor marqués de Gibraleón”; 6 reales por otras tantas libras de engrudo "para dar tinta a los paños de los arcos del túmulo"; 3 reales a los dos peones que se ocuparon un día "haziendo los hoyos y trayendo madera de la costa para el túmulo"; 27 maravedíes por el transporte de 8 tirantes de madera desde el monasterio dominico de Santo Domingo, situado en el Barrio Bajo, a la parroquia, y 85 maravedíes "por meter la madera del túmulo"; o 4 reales al pintor Diego López "porque molió dos días de prieto que se dio en el dicho túmulo”. El mercader flamenco Cornieles Quinderi, vecino de Sanlúcar, vendió la clavazón y otros materiales, empleándose 11.000 tachuelas (1.122 mrs.), 1.300 clavos de medio tillado (390 mrs.), 200 clavos de tillado (3 reales), 80 clavos timoneros (229 mrs.), 400 clavos de bota (70 mrs.), 4 libras de engrudo "para pegar el lienço en las tablas" (160 mrs.), 9 onzas “de Brasil para teñir la napa” y aderezar los reposteros que decoraban (17 mrs.), 12 onzas de hilo blanco casero y 6 agujas para coser los lienzos (600 mrs.), y 200 cañones de candeleros de hoja de Milán (600 mrs.) para luminarias. Como vemos, se hicieron en el suelo de la parroquia unos agujeros a modo de cimentación, que sirvieron para montar la estructura de madera, material que llegó por mar hasta el puerto sanluqueño, empleándose 8 tirantes y gran número de elementos metálicos de fijación para su fortaleza. Posiblemente de cierta entidad y varios cuerpos superpuestos, se organizaba con arcos, que por fechas serían de medio punto, quedando enmascarada la madera con lienzo teñido de negro, que lograba dar uniformidad al conjunto, completando la decoración varios reposteros que fueron restaurados, escudos con su heráldica y buen número de luminarias 9 . El montaje lo hizo en cinco días el carpintero ducal Juan Cordero con ayuda de los oficiales Baltasar Hernández, Juan Palomino y Alonso Muñoz, que cobraron cada día 3 reales, y del peón Juan de Ribas, 2 reales, que además utilizó varios tirantes que sobraron del monumento del Jueves Santo "y las que dél quedó, volvió a servir en el túmulo", mientras que los pintores

\footnotetext{
${ }^{9}$ Libranzas de la condesa del 13 de abril al 2 de junio de 1559. AFCMS leg. 2.546
} 
Francisco Montero y Baltasar de Funes, vecinos de la ciudad, cobraron 4 ducados "por los escudos que hicieron para el túmulo de las onrras", cantidad en la que se incluyó "lo que trabajaron en moler las tintas y teñirlo de negro"10.

\subsection{Honras por el VI duque de Medina Sidonia Don Juan Alonso Pérez de}

Guzmán $(+1558)$ y posteriormente por el traslado de sus huesos (1565)

La epidemia que asoló Sanlúcar en 1556 también se cebó en la familia ducal. El 24 de enero acabó con la vida del conde de Niebla y heredero del título, Don Juan Claros, y al poco enfermó su esposa Doña Leonor, nombrada curadora de sus hijos menores, que lograría reponerse, pero no así su suegra, la duquesa Doña Ana de Aragón, que falleció el 17 de julio. Fue enterrada, junto a su hijo, en el convento de Santo Domingo, que se estaba construyendo a costa de las arcas ducales, hasta donde se llevó solemnemente el ataúd, forrado de terciopelo, seguido por setenta pobres con capirotes de anascote y, aunque su marido el VI duque superó la enfermedad, moriría el 26 de noviembre de $1558^{11}$. Su nuera Doña Leonor, que quedó al frente de la Casa, fue la encargada de preparar sus exequias. El mercader jerezano Felipe Garzona suministró el $1^{\circ}$ de diciembre las 116 varas de paño negro que hicieron falta para recubrir el túmulo de madera que se levantó también en Santo Domingo y para las ropas de luto, que costaron 65.076 maravedíes, librados el 14 de abril de 1559. Y encomendó 105 misas a celebrar en el convento, desde el domingo 27 de noviembre al martes 6 de diciembre, de ellas 9 cantadas con sus vigilias, y las restantes rezadas ${ }^{12}$.

Tras terminar el convento y su iglesia, esta señora la consideró panteón destinado únicamente a su esposo e hijos, y decidió el traslado de los restos de sus suegros, los VI duques, al monasterio de San Isidoro del Campo en Sevilla, también de su patronazgo. Para honrarlos, el carpintero ducal Juan Cordero levantó un sencillo túmulo "en que se pusieron los huesos de los duques, mis señores, en el monasterio de Santo Domingo de Guzmán, quando se llevaron a Sevilla”, por el que el 4 de enero de 1565 recibió 16 reales y medio. El traslado de los restos los efectuó

${ }^{10}$ Libranzas de la condesa del 3, 15 y 18 de abril de 1559. AFCMS leg. 2.544. CRUZ ISIDORO, Fernando: "El Convento de Santo Domingo de Sanlúcar de Barrameda: patronazgo de los Guzmanes, proceso constructivo y patrimonio artístico (1528-1605)". Laboratorio de Arte, 23, Sevilla, 2011, pp. 88-89.

${ }^{11}$ ÁlVAREZ DE TOLEDO, Luisa, XXI duquesa de Medina Sidonia: Alonso Pérez de Guzmán, General de la Invencible. Libro 1º . Cádiz: Universidad, 1994, pp. $22-23$.

${ }^{12}$ AFCMS leg. 2.545; leg. 943. CRUZ ISIDORO, Fernando: "El Convento de Santo Domingo de Sanlúcar”... op. cit., p. 86. 
el criado Martín de Ribera, al que se entregaron, para gastos, 60 ducados el 31 de octubre ${ }^{13}$.

\subsection{Honras por la reina Doña Isabel de Valois $(+1568)$}

Tercera esposa de Felipe II, su fallecimiento por aborto tuvo lugar en octubre de 1568, un año horrible para el monarca, al sumarse esta desgracia a la muerte de su heredero el príncipe Don Carlos, lo que motivó su refugio ese otoño en el monasterio de El Escorial. El túmulo, que se levantó igualmente en la Parroquia de la $\mathrm{O}$, fue realizado por el Maestro mayor de las obras ducales el carpintero Francisco Rodríguez, y los carpinteros Alonso Muñoz, Rodrigo Rodríguez y García de Castro, que cobraron cada uno 4 ducados, mientras que los mozos Alonso y Pedro recibieron 3, recibiendo parte de sus jornales el 16 de octubre de ese año ${ }^{14}$.

\subsection{Honras y Aniversario por la VII duquesa Dña. Ana de Silva y Mendoza (+1610)}

Esposa del VII duque Don Alonso Pérez de Guzmán, su fallecimiento se produjo en mayo de 1610, cuando estaban empeñados en la construcción del Santuario de Ntra. Sra. de la Caridad. Sin embargo, sus honras no tuvieron lugar en su fábrica, inconclusa, sino en la iglesia del convento de clarisas de Regina Coeli, también bajo su patronato, y que la duquesa había logrado terminar, con trazas y dirección del arquitecto Alonso de Vandelvira, con su capilla mayor, coros alto y bajo, y su interesante fachada de doble portada al viario, modelo para las americanas. El diseño y ejecución del túmulo corrió de mano del Maestro mayor de obras ducales Bartolomé Rodríguez, en verdad maestro cañero y no de muy buen oficio, al que se libraron el 22 de mayo 976 reales para pagar los jornales de los artífices "que la semana pasada trabajaron haciendo el túmulo para el entierro y novenario de la duquesa, que está en el cielo"15. Su cadáver, no obstante, fue enterrado en la cripta de la iglesia de la Caridad, fundación concebida como panteón personal. Para conmemorar el Aniversario de su fallecimiento, al año siguiente se levantó un túmulo en la iglesia de las dominicas de Madre de Dios, ordenándose entregar al carpintero Juan de Bonilla el 4 de mayo de 1611 cuatro docenas de

${ }^{13}$ AFCMS leg. 2.570, leg. 2.568 fol. 6 vto.; leg. 2.565. CRUZ ISIDORO, Fernando: "El Convento de Santo Domingo de Sanlúcar..." op. cit. p. 91.

${ }^{14}$ AFCMS leg. 2.570 fol. 49 vto.

${ }^{15}$ RODRÍGUEZ DUARTE, $\mathrm{M}^{\mathrm{a}}$ del Carmen: El Convento de Regina Coeli. Un modelo de vida monástica en la Sanlúcar del Barroco. Sanlúcar de Barrameda: Ayuntamiento, 1998 , p. 285, nota 53. 
tablas para confeccionar los hacheros "para las honras de mi señora, que está en el cielo"'16.

\subsection{Honras por el VII duque Don Alonso Pérez de Guzmán (+1615)}

Capitán General de las Costas de Andalucía y del Mar Océano, y General de la Invencible, jugó un papel relevante en el devenir de Andalucía occidental y en la España del momento ${ }^{17}$. De sus honras tenemos cumplida noticia por la huella dejada en la contabilidad ducal, en las actas capitulares sanluqueñas, y por la ágil relación escrita por el poeta Pedro de Espinosa, en verso, Relación de la forma que se tuvo en el entierro. ${ }^{18}$, y en prosa, Elogio al retrato, escrita diez años más tarde, en $1625^{19}$. Espinosa fue rector del Colegio de Niños de San Ildefonso, asociado al Santuario de la Caridad, que fundó y costeaba el duque, por lo que no ha de extrañarnos la amargura que su fallecimiento causó en la institución, totalmente dependiente de su generosidad. Don Alonso murió el 26 de julio de $1615^{20}$, y ese mismo día fue informado el cabildo municipal, que decretó "es muy a razón questa zibdad se ponga luto", mandando a Jerez por "las vayetas que fuere menester para los lutos de la Justicia y Regimiento y Oficiales del Cabildo”, que se pagaría con las rentas de las carnicerías. Al día siguiente, se presentó al cabildo presidido por el corregidor Acevedo de Fonseca, Luis de Silva Enríquez, apoderado del primogénito del duque y su heredero, Don Manuel, para informar que éste ya había tomado posesión del título y anexos, solicitando que la Ciudad aceptase su tenencia con su jurisdicción anexa, de mero y mixto imperio civil y criminal, lo que fue aprobado. En el acto, todos desistieron de sus cargos, y le entregaron las varas de corregidor, alguacil mayor, alcalde de cuentas y demás varas de justicia y los oficios de alférez mayor, alcaide de la cárcel, padre de menores, escribanos de cabildo etc., para que nombrase a las personas que creyese más oportunas ${ }^{21}$.

${ }^{16}$ AFCMS leg. 2.890. CRUZ ISIDORO, Fernando: "Aporte documental al mecenazgo artístico de los VII y VIII duques de Medina Sidonia", Sanlúcar de Barrameda, 42, 2006, p. 129.

17 ÁlVAREZ DE TOLEDO, Luisa, XXI duquesa de Medina Sidonia: Alonso Pérez de Guzmán... op. cit.; Casa Medina Sidonia de Juan de Guzmán a Gaspar de Guzmán (14921664). (Notas Genealógicas, 2). Sanlúcar de Barrameda, Fundación Casa Medina Sidonia, 2008, pp. 21-33.

${ }^{18}$ ESPINOSA, Pedro: Poesías completas, ed. prol. y notas de Francisco López Estrada. Madrid: Espasa Calpe, 1975, pp. 154-164.

${ }^{19}$ Recogido en el apéndice de Zambrano, Alejando: La Virgen de la Caridad. Patrona de Sanlúcar. Jerez, 1952, pp. 68-73..

${ }^{20}$ VELÁZQUEZ GAZTELU, Juan Pedro: Catálogo de todas las personas ilustres..., op. cit. pp. 233-234.

${ }^{21}$ AMSB libro de actas capitulares de los años 1612 al $1618 \mathrm{n}^{\circ} 4.711$ fols. 89-93 vto. 
Por Espinosa sabemos que a Don Alonso se le amortajó con el hábito dominico, pues la Orden era considerada "propia", al ser su fundador Santo Domingo de Guzmán y por haber sido nombrado el duque Patrono de la religión en Andalucía. Sin embargo, no dudaron en colocarle su espada y espuelas doradas, símbolos de su status y función militar. Fue depositado en una caja de plomo, que luego se introdujo en otra de cedro guarnecida de terciopelo negro tachonado de oro, y como no podía ser menos, toda la celebración se centró en la que había sido su más personal fundación, el Santuario de la Caridad. En su capilla mayor se levantó un túmulo, a cargo de la familia, diseñado por su maestro mayor Bartolomé Rodríguez, del que Espinosa dirá: "La artificiosa traza, la valiente arquitectura, a su inventor ha hecho famoso en propia y estranjera gente Por remate del túmulo, derecho, pendía gravemente el estandarte, cuya punta tocó el dorado techo, digo, la insignia real que, para el arte de la milicia, al General que ampara el océano todo entregó Marte. El túmulo era negro, más con rara pompa; las hachas, de amarilla cera, su noche hacían, reluciente y clara. Tantas eran las luces, que, si fuera con proporción esférica formado, el estrellado globo pareciera. En el segundo cuerpo relevado del gran túmulo estaba su Excelencia, gran Duque ayer, hoy cuerpo inanimado; a cuya cabecera, en la eminencia, por General de nuestra Andalucía, hizo el regio guion grave apariencia". De planta centrada de tres cuerpos decrecientes y orden jónico, datos que ofrece el poeta en su relato en prosa, por las libranzas sabemos que se cubrió con 208 varas y media de tela negra de anascote, por valor de 36.133 mrs., pagados al vecino de Sanlúcar Pedro Rodríguez el 22 de septiembre, y que no pudieron reaprovecharse porque "se consumieron en el dicho túmulo por estar llenas de cera y maltratadas". Aparte, para vestir de luto a los caballeros, pajes y criados de la Casa, se adquirieron varas de damasco, piezas de bayeta negra, lanilla y anascote tafetán por la elevada cantidad de 4.423 reales, encargándose de la confección los sastres Cristóbal de Berrones, Juan Bautista, Juan Sánchez, Francisco García y Antón García, junto a sus oficiales, que cobraron otros 1.835 reales $^{22}$.

Como era de esperar, se formó una magna procesión el 29 de julio para trasladar el cadáver desde el palacio hasta el cercano Santuario. Abrió la marcha la milicia ducal, formada por siete compañías de arcabuceros vestidos de negro, que en la relación poética cifra en 500, número aceptable, y en la de prosa eleva a 4.200 hombres, quizás para magnificar el acto, seguidas de la escuadra de piqueros, cuyas lanzas pintadas también de negro iban arrastrando los hierros, con un lamentoso chirriar. Luego marchaban los pobres de la localidad, a los que se enlutaron con lobas de bayeta, con velas encendidas, en número de 100 en el poema y 220 en el relato de 1625, y a continuación los 40 colegiales de San Ildefonso (adviértase que su santo patrono también lo era del duque) con velas de a libra, y el

${ }^{22}$ AFCMS leg. 2.915 fol. 11 vto., 13 vto.; leg. 2.914 fols. 294 y vto. 
clero de Ntra. Sra. de la O en torno a la cruz parroquial entre cuatro ciriales de plata. La presencia de las religiones fue apabullante, pues todas estaban agradecidas por sus fundaciones en el vasto Estado ducal, que sumaban veintidós edificios entre conventos, hospitales y colegios ${ }^{23}$. Hicieron acto de presencia, según el poema o el relato, veintiocho o noventa hermanos de San Juan de Dios, ochenta o cien mínimos de San Francisco de Paula con su Provincial, ochenta y seis o ciento veinticuatro agustinos, cien o ciento veinte franciscanos, cien o ciento cuarenta y ocho dominicos, ochenta y cuatro miembros del clero secular de Sanlúcar que formaba parte de la hermandad sacerdotal de San Pedro, exhibiendo su guión, con capas de terciopelo negro y cetros de plata, cerrando el Vicario con capa de brocado negro escoltado por diáconos con sus dalmáticas. Tan numerosa presencia de frailes ha de entenderse porque a las comunidades asentadas en la ciudad se unieron los que esperaban embarcar para América y los de los demás conventos fundados por el duque, algunos llegados de Sevilla en la barcaza "de la vez", que hacía diariamente el trayecto entre ambas poblaciones por el Guadalquivir. Luego marchaba la rica capilla musical del Santuario con su maestro de capilla al frente, que antes había sido del palacio, pero que el duque trasladó a su fundación, entonando tristes y acompasados sones, siguiendo los vecinos de Sanlúcar según su posición social, y representantes de las otras villas, y caballeros vasallos. Seguían el mayordomo y camarero del duque, portando el bastón de mando y tremolando el estandarte de Capitán General, desde su caballo enlutado, Don Fernando de Olivares, gentilhombre de la Casa. Debió resultar impresionante y patético, ver la tristeza y alaridos del reconocido caballo del duque, sin herraduras y con los ojos cubiertos, "con silla de borrenas acerada", cubierto con una gualdrapa de terciopelo negro, con muchas puntas de las que pendían borlas de seda, que arrastraban, llevando en la testuz, pecho y anca derecha tres escudos de los Guzmanes, bordados en campo negro, y delante suyo cuatro criados enlutados y otros dos que lo llevaban del bozal, mientras dos sotacaballerizos, que iban detrás, lo golpeaban con dos varas negras, provocándole unos lamentos que llegaron a lo más hondo de los vasallos. A pie marchaba el caballerizo mayor Don Francisco de Olivares, con la cabeza cubierta de capuz, seguido por dos maceros con mazas doradas que escoltaban a un rey de armas con cetro del mismo tono, vestidos con lobas sobre las cotas de armar, bordadas de seda carmesí, con los escudos de armas en pecho y espalda. A continuación, marchaba el cadáver, al que daban luz cuatro acólitos con dalmática de brocado portando ciriales de plata y otros cuatro con dalmáticas de brocado negro e incensarios, daban continuamente humo al féretro, que se desdibujaba a los ojos de los súbditos. La caja

${ }^{23}$ CRUZ ISIDORO, Fernando: "El mecenazgo arquitectónico de la Casa ducal de Medina Sidonia entre 1559 y 1633”, Laboratorio de Arte, 18, 2005, pp. 178-179. 
iba cubierta de terciopelo negro, atravesado por una cruz de damasco carmesí ${ }^{24}$, "que en la guerra es insignia fiel de nuestra España". La cargaban seis hombres, al principio el marqués de Ayamonte, Don Francisco Duarte y otros cuatro nobles, y a sus lados marchaban doce o dieciséis capellanes del duque, que iban cantando loores, y detrás los regidores del cabildo municipal de Sanlúcar, Medina Sidonia y sus seis villas, los diecisiete lugares del condado de Niebla, de los tres lugares de la frontera, Niebla y sus cinco villas, y las restantes por su orden, culminando con su heredero y primogénito el VIII duque Don Manuel, que ya ostentaba el Toisón encima de su loba de luto, acompañado de sus hermanos fray Felipe de Guzmán, Don Alonso, Don Miguel y Don Juan Claros, escoltados por señores de alcurnia, como el marqués de Ayamonte, y sus respectivos criados. Guardaron las bocas de las calles y escoltaron el recorrido doscientos infantes. Desde el palacio hasta el Santuario se hicieron cinco relevos y paradas, entrándolo en la iglesia los caballeros, aunque fueron los capellanes los que depositaron el ataúd en el túmulo. El oficio funerario fue solemnísimo, y tras acabar se abrió el féretro para autentificar el cadáver, y pusieron en su interior sus bastones de mando el mayordomo y el camarero mayor. El ataúd fue depositado, junto al de su esposa Doña Ana de Silva, en el hueco previsto bajo el retablo mayor, en el que el duque había dispuesto numerosas reliquias y la propia Virgen de la Caridad, por tanto bien custodiado, y donde continúa. De forma seguida, los maceros volvieron su rostro al pueblo congregado, y a viva voz el rey de armas pregonó su muerte: "Sabed que Don Alonso Pérez de Guzmán, séptimo duque de esta Casa, es muerto, roguemos a Dios por él", pasando a continuación a proclamar a su heredero: "Señor Don Manuel Alonso Pérez de Guzmán el Bueno, duque de esta Casa, es heredero de estos Estados, recibidle por Señor y dadle la enhorabuena", tremolando el estandarte su gentilhombre de cámara y alcaide de Huelva Don Gonzalo de Castilla, momento en que comenzó la música, con el órgano, cantores y ministriles, y luego repicaron las campanas, para llevar tan triste y al tiempo feliz evento hasta los mismos cielos. Las ordenadas compañías de arcabuceros y piqueros enarbolaron banderas y un escuadrón montó guardia delante del palacio, rindiendo sus capitanes obediencia al paso del nuevo duque. En los nueve días siguientes, se ofició un novenario con misa y sermón, y por su alma se dijeron 2.000 misas, de ellas 800 en el

${ }^{24}$ Se confeccionó con 5 varas de damasco carmesí "para una cruz que se hizo para poner en el paño de terciopelo con que se enterró el duque mi señor, a 27 reales la vara, 135 reales". AFCMS leg. 2.915. 
propio Santuario ${ }^{25}$. Como vemos, un ceremonial que nos recuerda, a escala, el seguido con los reyes hispanos ${ }^{26}$.

3.7. Honras por la VIII duquesa Dña. Juana de Rojas Sandoval y la Cerda (+1624)

Hija mayor del Primer ministro y valido de Felipe III, el I duque de Lerma Don Francisco de Rojas y Sandoval y de la duquesa Doña Catalina de la Cerda, casó con el VIII duque Don Manuel en el Palacio Real de Madrid en noviembre de 1598. Su muerte tuvo lugar en Sanlúcar el 15 de agosto de 1624, festividad de la Asunción y día en que procesiona por la ciudad la Patrona del Estado ducal, Ntra. Sra. de la Caridad. Su cadáver fue depositado en el panteón del convento de la Merced, su personal fundación ${ }^{27}$. Parte de las honras debió costearlas el cabildo municipal, porque tres días más tarde se informó en reunión que, "por no tener de presente la Ciudad dineros", se veía obligada a pedir prestado a varios señores la cantidad de 2.408 reales, con los que sufragar la bayeta negra para vestir a sus oficiales, pero por la cuantía parece que también corrió con parte del ensamblaje del correspondiente túmulo ${ }^{28}$.

\subsection{Honras por la IX duquesa Doña Ana de Aragón (+1637)}

La última hija de los VII duques Don Alonso y Doña Ana, casó en 1622 con su sobrino el IX duque Don Gaspar, y falleció el 13 de agosto de 1637, a los 30 años de edad, siendo sepultada en el Santuario de la Caridad, bajo el retablo mayor, junto a sus padres ${ }^{29}$. El día de su muerte, el corregidor manifestó la noticia al cabildo municipal, acordándose los lutos acostumbrados, entregando "a cada capitular dose varas de bayeta"30. Las honras se realizaron en el Santuario de la Caridad, empleándose "seis tablas para listones pare el túmulo que se hace en la Charidad para las onras de las duquesa, mi señora"31.

${ }^{25}$ ESPINOSA, Pedro, obras citadas. CRUZ ISIDORO, Fernando: El Santuario de Ntra. Sra. de la Caridad, de Sanlúcar de Barrameda. Estudio histórico-artístico. Córdoba: CajaSur, 1997, pp. 59-60.

${ }^{26}$ SALAS ALMELA, Luis: Medina Sidonia. El poder de la aristocracia 1580-1670. Madrid, 2008, pp. 56-58.

27 VELÁZQUEZ GAZTELU, Juan Pedro: Catálogo de todas las personas ilustres... op. cit. p. 234.

${ }^{28}$ AMSB Libros de actas capitulares leg. 4.712 fol. 231.

${ }^{29}$ VELÁZQUEZ GAZTELU, Juan Pedro: Catálogo de todas las personas ilustres... op. cit. p. 240.

${ }^{30}$ AMSB Libro de actas capitulares de los años 1637-1640 leg. 4.715 fols. 19 vto. y 20.

${ }^{31}$ AFCMS leg. 3.137. 


\subsection{Honras por la marquesa de Ayamonte (+1639)}

El IX duque Don Gaspar ordenó librar al receptor Fernando de Segura Galván el 16 de abril de 1639, la suma de 111 reales al carpintero Alonso de Velasco, "por la manufactura de el túmulo que se hiço para las honras de mi señora la marquesa de Ayamonte, que está en el cielo, y capas para el cuerpo de su Excelencia"32.

\subsection{Honras por el marqués de Villamanrique Don Melchor de Guzmán (+1639)}

Cuarto hijo de los VIII duques Don Manuel y Doña Juana, nació en Madrid en diciembre de 1607, y adquirió el título de marqués al casar en 1623 con Doña Josefa Luisa Manrique de Zúñiga, hija de los II marqueses de Villamanrique. Falleció en Sanlúcar el 22 de julio de 1639, siendo sepultado con sus progenitores en el panteón del convento de la Merced $^{33}$. Allí se levantó el túmulo, ordenando librar su hermano el IX duque Don Gaspar el 27 de ese mes, 297 reales y medio a los carpinteros para su ensamblaje, y 28 reales para los jornales de "los pintores que dieron de negro el túmulo que para el señor marqués de Villamanrique, mi hermano, que está en el cielo, se hiço en la iglesia de Ntra. Sra. de la Merced"34. En esos momentos ocupaba la plaza de "Maestro mayor de mi Casa” Martín Rodríguez de Castro $^{35}$, que lo era al menos desde 1634, tracista y constructor del sanluqueño convento de Capuchinos ${ }^{36}$.

\section{LA EXALTACIÓN DEL SANTÍSIMO: LOS MONUMENTOS EUCARÍSTICOS DEL JUEVES SANTO}

Se levantaban anualmente en la parroquia palatina de Ntra. Sra. de la O, inmediata al palacio ducal, en la iglesia conventual de Santo Domingo y, posteriormente, en el convento de dominicas de Madre Dios, tras la terminación de ambas fábricas por la condesa de Niebla Doña Leonor (madre del VII duque). Posiblemente con diseño del Maestro de obras ducales de turno, solía contratarlos el carpintero ducal ayudado por otros operarios que trabajaban a jornal, y su huella documental ha quedado en las libranzas junto con las del material empleado:

${ }^{32}$ AFCMS leg. 3.156 fol. 118 vto.

33 VELÁZQUEZ GAZTELU, Juan Pedro: Catálogo de todas las personas ilustres.. op. cit. p. 241.

${ }^{34}$ AFCMS leg. 3.150 fols. 177 vto., 179.

${ }^{35}$ Libranza del 17-I-1639 de 213' 5 reales para que pagase los jornales de los albañiles y carpinteros que se encontraban a sus órdenes trabajando en el palacio ducal. AFCMS leg. 3.156 fol. 19 vto.

${ }^{36}$ CRUZ ISIDORO, Fernando: El convento sanluqueño de Capuchinos...op. cit. pp. 46-51. 
madera, telas y lienzos. El que fueran efímeros parece avalarlo las libranzas ducales a otros carpinteros, distintos a los que contrataban su montaje, para posteriormente efectuar su desmontaje. Caso diferente, como hemos comentado, parece haber sido el Monumento del convento de Madre de Dios, pues su hechura monumental columnaria servía de un año para otro, necesitando sólo de un ligero montaje mecánico.

La forma de estos Monumentos debió ser la habitual, de cuerpos superpuestos decrecientes, para disponer en la parte superior un ostensorio con el Viril de la Sagrada Forma. Para abaratar costes, algunos elementos lujosos se conservaban de un año para otro, como los manteles de tela adquiridos en 1576 para el de la parroquia para "unos pilares aforrados de lienço, que se guardaron para los años venideros" 37 .

Uno de las primeros Monumentos que hemos podido documentar es el de la parroquia del año 1546. Se conserva la orden de libranza del VI duque D. Juan Alonso de 22 de marzo al criado y recaudador Diego de Dueñas para que entregase al carpintero Vázquez, sin citar el nombre, pero sí que era "mi vasallo desta mi villa de Sanlúcar", la cantidad de ducado y medio "para comprar ciertos rostros de pintura en Sevilla y los a de hacer para el Monumento de la Iglesia mayor desta dicha mi villa"38. Curioso dato, que nos habla de las pinturas alegóricas con las que se enriquecía la estructura de madera, dándole color y el necesario contenido simbólico que se pretendía exponer al gran público, alusivas al valor sacrificial eucarístico, como las representaciones del Pelícano eucarístico, Ave fénix..., o prefiguraciones sacerdotales del Antiguo Testamento que solían aparecer en ocasiones, caso de Melquisedec o el rey David, semejantes a las barrocas que se conservan en Sanlúcar en el monasterio de Madre de Dios, procedentes del clausurado jerezano del Espíritu Santo de la misma orden dominica femenina, y que nos podrían dar el tono de estas estructura triunfales efímeras.

Al menos desde 1559 se montaban dos Monumentos en Sanlúcar, sufragados por la Casa ducal. Para el que se levantó en la parroquia hicieron falta "quatro carros de tirantes para el Monumento de la iglesia mayor desta villa, a diez y seis reales el carro", que costaron 64 reales por orden de libranza de la condesa Doña Leonor en el tesorero ducal Luis de Cabrera de 3 de abril. El sobrante de madera sirvió, como se ha visto, para el túmulo del marqués de Gibraleón, y el resto se guardó en las atarazanas ducales ${ }^{39}$. El de Santo Domingo lo montó el Maestro mayor Francisco Rodríguez, que empleó 6 días junto a los carpinteros Juan de

\footnotetext{
${ }^{37}$ AFCMS leg. 2.641 fols. 216 vto, 217.

${ }^{38}$ AFCMS leg. 2.497.

${ }^{39}$ AFCMS leg. 2.546.
} 
Luna y Juan García León, por 18, 8 y 9 reales respectivamente, según libranza de la condesa de 12 de mayo $^{40}$.

Igualmente localizamos la contabilidad de los costeados en 1565. Como en aquellos momentos la condesa Doña Leonor pasaba una temporada en Medina Sidonia se levantó uno de cierta entidad en su parroquia mayor. Lo confeccionó el habitual Juan Cordero, al que la condesa ordenó librar el 20 de abril la suma de 6.000 maravedíes "porque hizo el Monumento que por mi mandado se hizo en la yglesia mayor desta ciudad”, y no cabe duda respecto a la población, pues marginalmente se dispone en la libranza: "A Juan Cordero, carpintero, que hizo el Monumento de Medina Sidonia”. Le ocupó quince día “a destajo”, ayudado por tres oficiales En su desmontaje trabajaron los carpinteros Garcí Jiménez, tres días por 14 reales, y Diego de Chillón, Bartolomé Lorenzo y Francisco "moço” día y medio”, a 6 reales los dos primeros y dos reales y medio el último ${ }^{41}$.

En Sanlúcar, el Monumento de Santo Domingo también debió ser de cierta monumentalidad, pues lo ensambló Francisco Rodríguez por 10 ducados, con libranza de la condesa del 26 de abril sobre el fiel ejecutor Pero Díaz, recaudador de las Rentas ducales de la Aduana, y en él se emplearon carro y medio de tirantes y cuatro de medios pontones. Trabajaron los carpinteros Diego de Çurita y Antonio Caballero y Collado, que emplearon 8 días "cosiendo los lienzos y colgando y haciendo el monumento". A Çurita, que tuvo un papel importante en su ejecución, se compró el 3 de abril la madera y el 17 entregó 4 varas de "bocaçin para el monumento de Santo Domingo", que quedó recubierto con 197 varas de tela de "vitre" que se compraron por 7.880 maravedíes al bretón Carlos Brochín y por los reposteros que se llevaron desde el palacio de Medina Sidonia, para lo que se alquiló un caballo por 4 reales en que fuese "maese Alonso, tapicero, a Medina, por cosas de la recámara para el Monumento, donde se detuvo dos días”. El color lo dio el pintor Antonio de Vitoria, que cobró el 22 de julio 8 ducados "para en quenta de lo que a de aver por el Monumento que pinto" y policromar y dorar "un coche para doña María, mi hija"42.

El Monumento de la parroquia de la $\mathrm{O}$ de 1576 ostentó una forma más rica al quedar sus "pilares aforrados de lienço", con seis manteles que se compraron al mercader inglés Guillermo Holdin por 60 reales, según libranza del VII duque Don Alonso de 14 de agosto, "que se guardaron para los años venideros", lo que entraña la idea de abaratar costes haciendo la estructura semiefímera, conservando parte de los elementos ${ }^{43}$. Su confección la ejecutó el carpintero Alonso

${ }^{40}$ AFCMS leg. 2.546. CRUZ ISIDORO, Fernando: "El Convento de Santo Domingo de Sanlúcar..." op. cit., p. 89.

${ }^{41}$ AFCMS leg. 2.568 fols. 31, 33.

${ }^{42}$ AFCMS leg. 2.568 fosl. 78, 80 vto., 82, 379 vto., 399 vto.; leg. 2.571. CRUZ ISIDORO, Fernando: "El Convento de Santo Domingo de Sanlúcar..., op. cit., p. 92

${ }^{43}$ AFCMS leg. 2.641 fols. 216 vto y 217. 
Ximénez, que a la par hizo el del monasterio de Madre de Dios, que costeó la condesa Doña Leonor, lo mismo que la terminación de su fábrica y ajuar litúrgico, y que se hizo construir en su interior un palacio para su retiro y el de una nieta ilegítima. El monumento conventual pudo estar inspirado en el mueble de microarquitectura que aparece como fondo del retrato que de la condesa pintó el maestro Cristóbal de Almería un año antes, en 1575, conservado en su Sala capitular $\operatorname{alta}^{44}$, y bien pudo ser trazado por el ingeniero y arquitecto italiano Juan Pedro Livadote, autor de la iglesia y palacio interior, presentando clasicista planta centrada, de cuatro columnas elevadas sobre pedestales. Doña Leonor ordenó librar a cuenta de su ensambladura a Ximénez 10 ducados el 7 de abril, y 121 reales el 8 de mayo, que sumaban 231 reales, en que concertó su hechura y la del que montó en la parroquia. En ambos empleó 5 docenas de berlingas de madera, por 120 reales, 56 tablas aserradizas, 14 tirantes (de los de 8 en carro) y 1 pontón (de los de 3 en carro), que le entregó el criado ducal Diego de Zamora. Las columnas y pedestales fueron policromados, imitando mármoles, por los pintores Francisco Vázquez y Juan Rodríguez, que cobraron 6 ducados el 12 de abril ${ }^{45}$.

También hay constancia documental del que se levantaba en el Santuario de la Caridad, como en 1615, cuando se libraron 60 reales el 18 de abril por los diez jornales del carpintero Juan de Bonilla, junto a sus oficiales, por "hacer y deshacer el Monumento" 46 .

La gran veneración que el VIII duque Don Manuel tuvo al Santísimo se refleja, finalmente, en el ostentoso Monumento, ya de carácter perdurable, que regaló a la parroquia de la $\mathrm{O}$, por valor de 4.675 reales " $y$ bale mucho más", como refleja el inventario efectuado el 15 de julio de 1623 por el vicario Luis de León Garabito y el bachiller Francisco Gutiérrez de Aguilar, mayordomo de la fábrica. La estructura, de madera y tela, se describe como "una cama rica de raso carmesí bordado de oro, con su madera dorada, que se pone el Jueves Santo para el monumento", que se coronaba con un cuadro grande de una Santa Cena, valorado en otros 900 reales. Completaban la escenografía teatral del presbiterio las ricas telas, que igualmente regaló, "de tafetanes carmesíes y amarillos listados, con que se cuelga toda la capilla mayor”, que costaron 2.600 reales $^{47}$. En 1627 el duque seguía

${ }^{44}$ CRUZ ISIDORO, Fernando: "Juan Pedro Livadote al servicio de la condesa de Niebla: el convento de Madre de Dios (1574-1576)”, Laboratorio de Arte, 22, 2010, p. 146.

${ }^{45}$ AGFMS leg. 2.641 fols. 66 y vto., 72, 114 vto., 399 vto. CRUZ ISIDORO, Fernando: "Juan Pedro Livadote..., op. cit., p. 147.

${ }^{46}$ AFCMS leg. 2.914 fol. 120 vto.

${ }^{47}$ AFCMS leg. 1.001. CRUZ ISIDORO, Fernando: "Aporte documental al mecenazgo artístico de los VII y VIII duques..., op.cit. p. 131. 
costeando su montaje, que ese año realizó el ensamblador de retablos Pedro de Castilla por 10 ducados, librados el 3 de abril ${ }^{48}$.

\section{LAS FIESTAS DE ESTRENO DE IGLESIAS CONVENTUALES PATRONADAS POR LA CASA}

Como no podía ser menos, dado el alto coste material que presuponía para los Guzmanes levantar una nueva iglesia conventual y, sobre todo, dotarla y asegurar con suficientes medios económicos la subsistencia de la comunidad que habitaba el convento, cuando se acababa su construcción y equipamiento litúrgico o, al menos, ya se podía celebrar misa con el suficiente decoro, la Casa procedía a su inauguración oficial, sufragando una ostentosa fiesta de estreno, en la que se invitaba a los diferentes sectores sociales a participar activa o pasivamente según su rango y afinidad con la comunidad. En esas fiestas no faltaban, por esencia, los actos litúrgicos propios para la consagración de los nuevos templos, como la ostentosa procesión de la comunidad, acompañada de otros miembros de su religión, procedentes de Sevilla y otras poblaciones del estado señorial, deudores de los Guzmanes, que eran escoltados por las demás órdenes de la ciudad y el clero secular, para trasladar con la debida honra el Santísimo desde el sagrario de la parroquia mayor hasta su entronización en el nuevo templo, lo que culminaba con solemne misa, donde el sermón se cuidaba al máximo por el predicador y la música elevaría el tono general, siendo la asistencia masiva. El acto quedaba aderezado con toda una serie de elementos festivos y lúdicos que lo hacían atractivo para el pueblo, como la limpieza y remozamiento general de las calles por donde tendría lugar la procesión, los continuos repiques de campanas de todas las iglesias, la erección de altares efímeros por el recorrido, las estruendosas salvas de artillería de las fortalezas y barcos anclados en su puerto de Bonanza, y de los mosquetes de la milicia local, el castillo de truenos que no solía faltar, la contemplación de sus señores desfilando acompañados de los regidores municipales, nobles afines y demás estamentos, todos con sus mejores galas, amén de otros actos complementarios, como los literarios, o juegos caballerescos que daban a ese tiempo el carácter de festivo sobre el ordinario.

\subsection{Fiesta de estreno del Santuario de Ntra. Sra. de la Caridad (1612)}

Fue organizada por el VII duque Don Alonso, y dio testimonio literario el citado dominico fray Pedro Beltrán en el Canto XIV de su Charidad Guzmana. A la misma acudieron la aristocracia bajoandaluza y su clerecía. Las celebraciones

${ }^{48}$ AFCMS leg. 3.020. CRUZ ISIDORO, Fernando: "Aporte documental al mecenazgo artístico de los VII y VIII duques..., op. p. 132. 
duraron nueve días, el de la Asunción y su Octava, o sea, del 15 al 23 de agosto. El 15, que era y es cuando se celebra la procesión de Ntra. de la Caridad, para la que se construyó el edificio, se solemnizó aún más si cabe el evento, pues en el recorrido participaron todas las hermandades, religiones, clero y nobleza de la ciudad, discurriendo por unas calles que se dignificaron al cubrirse con juncias y ramos, que daban olor y frescor y a la vez ocultaban la suciedad propia del momento, mientras que las casas se enmascararon con innumerables colgaduras, que daban un aspecto más clasicista, a la ciudad, quedando salpicado el viario de altares efímeros, arcos triunfales y pasos o tablados cargados con escenas simbólicas realizadas en madera. Aparte de a los ocho sermones de su Octava, las tardes se dedicaron a festejos profanos. El primer día fiesta de toros y cañas; el segundo, representaciones teatrales en varias plazas de la ciudad; el tercero alardes caballerescos; el cuarto, se rifaron regalos consistentes en sedas, paños, vajillas, joyas... por valor de más de mil ducados; el quinto los nobles compitieron en el juego de la sortija, para ver quien arrancaba con la mano la cabeza de alguno de los diez gansos que se colgaron; el sexto hubo una regata de veinte barcas de remeros; el séptimo torneo incruento de caballeros; y el octavo, un simulacro de batalla naval por la costa sanluqueña; y la postrera, una justa literaria de español, griego y latín. Todas las noches los actos concluían con los tradicionales cohetes, tracas y fuegos de artillería, y se quemaba una invención de madera, cartón y pólvora, a saber: un gigante a modo de Atlas, un toro, un dragón, un galeón, un árbol... Los premios a los ganadores de cada concurso se entregaron a sones de trompetas y chirimías en la iglesia recién inaugurada, siendo de destacar que el conde de Niebla Don Manuel recibió el galardón por un carro en el que se representó el Santuario en miniatura con todos sus enseres ${ }^{49}$.

\subsection{Fiesta de estreno de la iglesia conventual de la Merced (1625)}

Levantado el convento a instancias de los VIII duques Don Manuel Pérez de Guzmán y de su esposa Doña Juana de Rojas Sandoval y la Cerda, que lo concibieron como panteón personal, con trazas y dirección de Alonso de Vandelvira y posterior participación de Juan de Oviedo ${ }^{50}$, su fiesta de estreno tuvo lugar el 12 de enero de 1625, domingo infraoctavo de la Epifanía. Para tan jubiloso evento, la iglesia fue adornada por la duquesa con "todo lo rico y precioso de su palacio", que suponemos tapices, plata y demás ornato. Los actos comenzaron en la parroquia mayor de la $\mathrm{O}$, donde predicó el padre fray Luis de Jesús María, comendador de los mercedarios de Sevilla y se consagraron dos Hostias, una de las cuales

\footnotetext{
${ }^{49}$ CRUZ ISIDORO, Fernando: El Santuario de Ntra. Sra. de la Caridad...op. cit., pp. 44-45.

${ }^{50}$ CRUZ ISIDORO, Fernando: Alonso de Vandelvira (1544-ca.1626727). Tratadista y arquitecto andaluz. Sevilla: Universidad, 2001, pp. 211-237.
} 
se dispuso en una custodia de plata para ser llevada solemnemente bajo palio en la procesión, tras acabar la función, sobre las 12 del mediodía, hasta el nuevo convento y ser depositada en su sagrario. La comitiva estuvo formada por todo el clero, las religiones por su orden, las hermandades, la nobleza y el pueblo, escoltando el palio con velas encendidas el duque y sus hijos. Durante el breve recorrido que separa ambos templos, no dejaron de disparar los artilleros de los castillos y navíos del puerto, a la par que repicaban todas las campanas de la ciudad. Cuando llegó el cortejo, se interpretaron diversos motetes, el preste bendijo con el Santísimo a los asistentes, y lo depositó en el sagrario, con lo que la fundación se hizo efectiva. La duquesa asistió desde una tribuna "que para sí había mandado hacer en la iglesia”. El altar mayor se transformó en un ascua de luces gracias a las numerosas luminarias que se colocaron. La duquesa sufragó el almuerzo de la comunidad ${ }^{51}$.

\subsection{Fiesta de estreno de la iglesia conventual de Capuchinos (1635)}

El mismo duque, diez años más tarde, procedió el 9 de enero de 1635 a la celebración del estreno de la que también fue una fundación personal, y único convento masculino que sigue en uso en la localidad, con trazas del maestro mayor ducal Martín Rodríguez de Castro. Tras sufragar su construcción y ajuar litúrgico, costeó la fiesta de estreno, que un principio se pensó para el 4 de octubre de 1634, festividad de San Francisco de Asís, pero la repentina muerte del General de los Capuchinos retrasó la finalización de las obras, al ausentarse el Guardián, o superior, a Sevilla. Al igual que la del convento de la Merced, se fijó su fecha para la festividad de Reyes, pero un fuerte temporal obligó a retrasarla hasta el día 9, "en que se trajo el Santísimo en una procesión, la más suntuosa que jamás se ha visto en Sanlúcar”. A lo religioso se unió lo profano. Desde Sevilla se desplazaron el antiguo Guardián, nombrado nuevo Comisario de la Orden, fray Félix de Granada, junto con 30 capuchinos de esa ciudad y 13 de otras comunidades cercanas, según la Reseña histórica de la Orden, que bajaron por el Guadalquivir en dos falúas, costeadas por el duque. Causó asombro al gentío congregado a las puertas del convento para ver entrar el Santísimo, la descarga de los mosquetes de la infantería señorial, marcialmente dispuesta en los aledaños y el camino, que fue preciso acondicionar para el evento, ya que trabajaron cuarenta portugueses allanando "los montones de arena y barro que avía sobre las barrancas de la huerta". El suelo se cubrió de juncias, flores y ramajes, que dieron la nota de olor, elevándose por trechos altares efímero, donde paraba la procesión del Santísimo,

${ }^{51}$ VELÁZQUEZ GAZTELU, Juan Pedro: Fundaciones de todas las iglesias, conventos y ermitas de la Muy Noble y Muy Leal ciudad de Sanlúcar de Barrameda. Transcrip. de Manuel Romero Tallafigo. Sanlúcar de Barrameda: ASEHA, 1995, pp. 357-359. 
que fue trasladado desde la parroquia de la O por el propio duque Don Manuel "con devoción tan fervorosa que edificaba a quién lo veía". El convento se engalanó con colgaduras. A la procesión asistieron todas las religiones, a pesar de los piques por el arraigo de una nueva comunidad de frailes mendicantes, la nobleza dependiente de la Casa, y el pueblo "con luces en sus manos". A pesar de la fiesta, la dedicación e inauguración oficial se retrasó hasta el día 14, en que pudo predicar el padre Bernardino de Quintanar, extraprovincial de Castilla. En ese intervalo, la cocina ducal suministró comida guisada a todos los frailes que acudieron al evento, para que no solicitasen limosna por las calles y para que uno estuviese siempre en oración ante el sagrario ${ }^{52}$.

Fecha de recepción: 20 de julio de 2014

Fecha de aceptación: 28 de noviembre de 2014

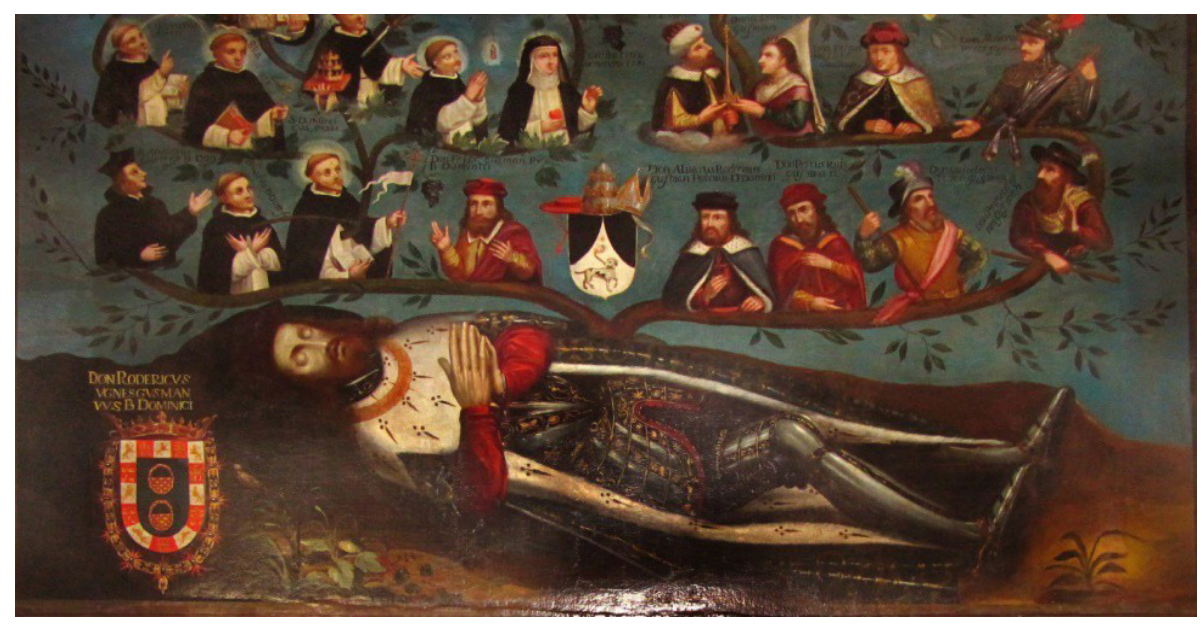

Figura 1. Genealogía de los Guzmanes. Francisco Juanete. 1612. Santuario de Ntra. Sra. de la Caridad, de Sanlúcar de Barrameda. Detalle del arranque del árbol genealógico.

${ }^{52}$ CRUZ ISIDORO, Fernando: La Casa ducal de Medina Sidonia y el convento de Capuchinos de Sanlúcar de Barrameda: Patronato y Construcción”, Laboratorio de Arte, 13, 2000, p. 92. El convento sanluqueño de Capuchinos...op. cit. pp. 63-65. 

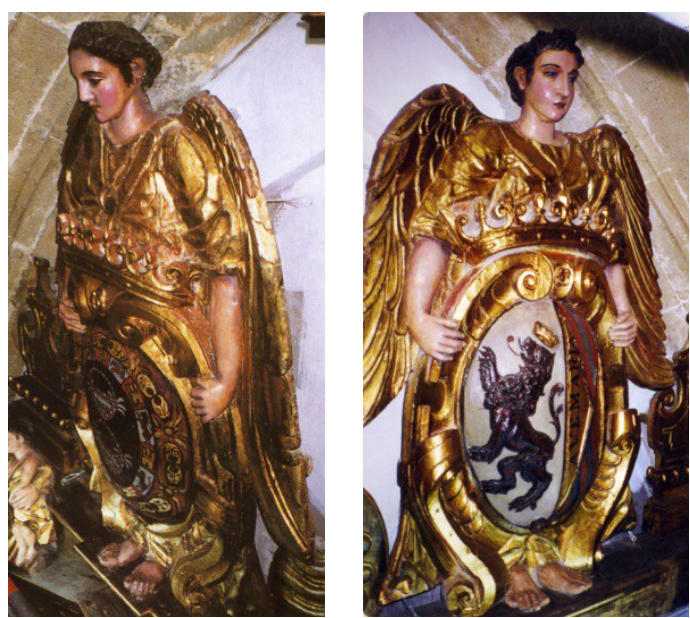

Figura 2. Ángeles tenantes. Martín Christiano y Hernando de Moya. 1612. Ático del retablo mayor del Santuario de Ntra. Sra. de la Caridad, de Sanlucar de Barrameda.

Escudos de Guzmán y Mendoza.

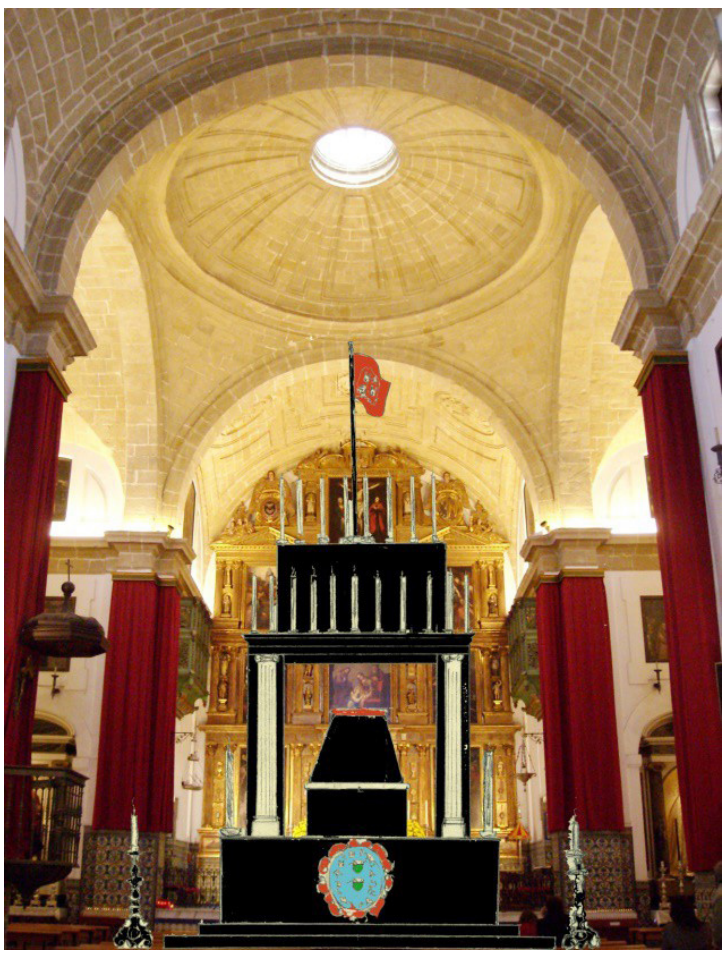

Figura 3. Recreación del túmulo funerario del VII duque Don Alonso Pérez de Guzmán. Santuario de Ntra. Sra. de la Caridad, de Sanlucar de Barrameda. Dibujo del autor. 

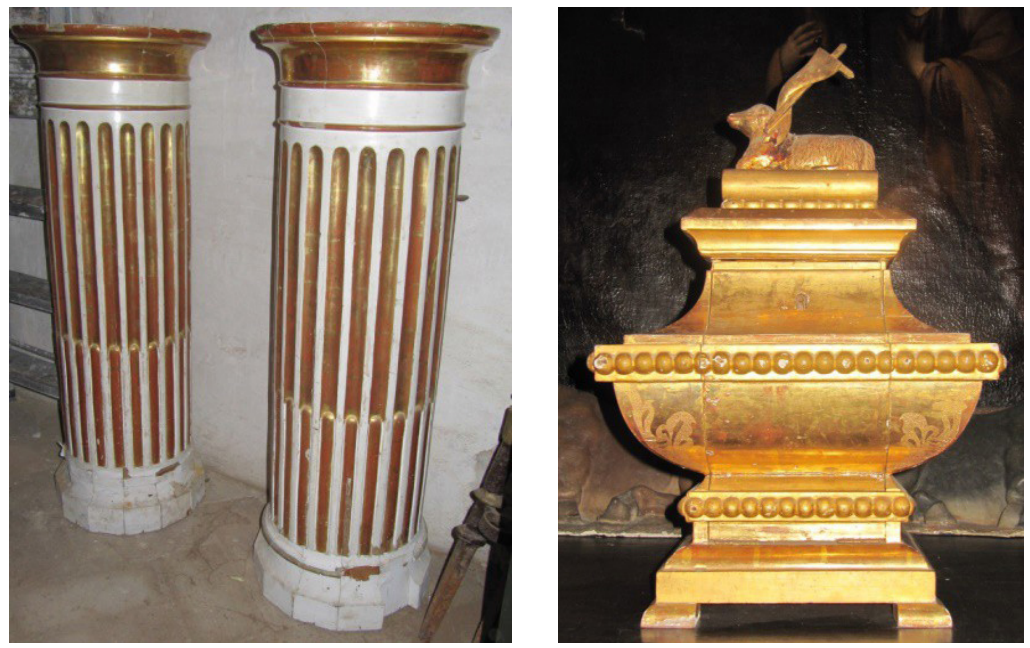

Figura 4. Elementos conservados del Monumento del Jueves Santo de la Parroquia Mayor ducal de Ntra. Sra. de la O, de Sanlúcar de Barrameda.
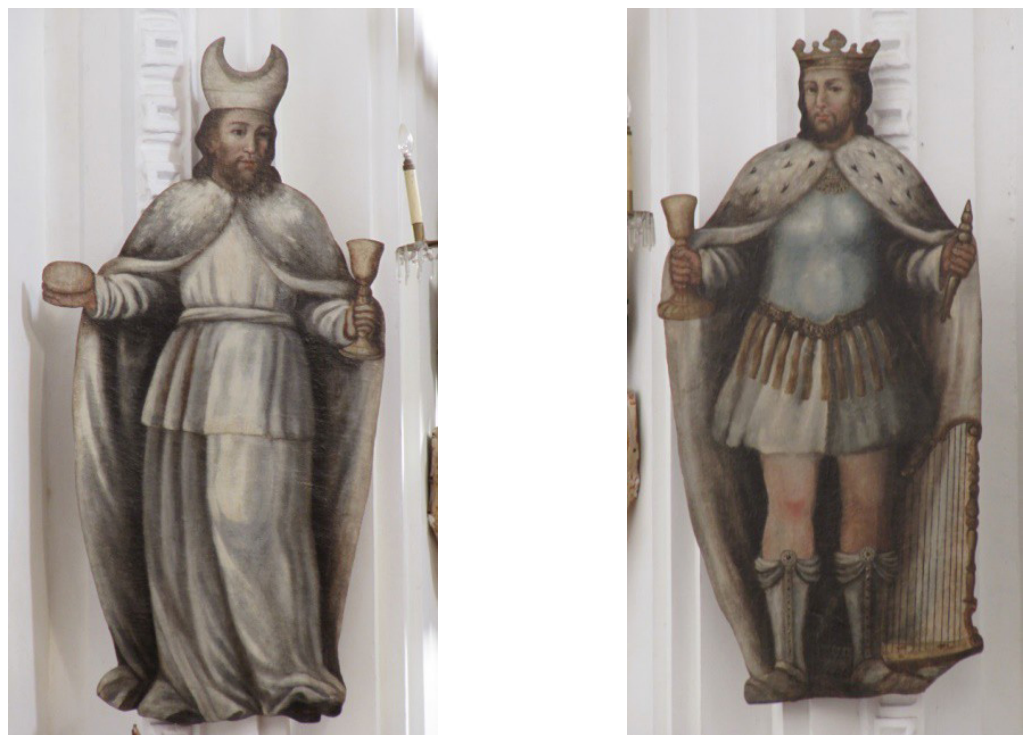

Figura 5. Óleos sobre lienzo fijado a tablas recortadas de Melquisedec y del Rey David. Anónimos de la segunda mitad del siglo XVIII.

Procedentes del Monumento eucarístico del convento dominico del Espíritu Santo de Jerez de la Frontera, actualmente en el monasterio de Madre de Dios de Sanlúcar de Barrameda. 


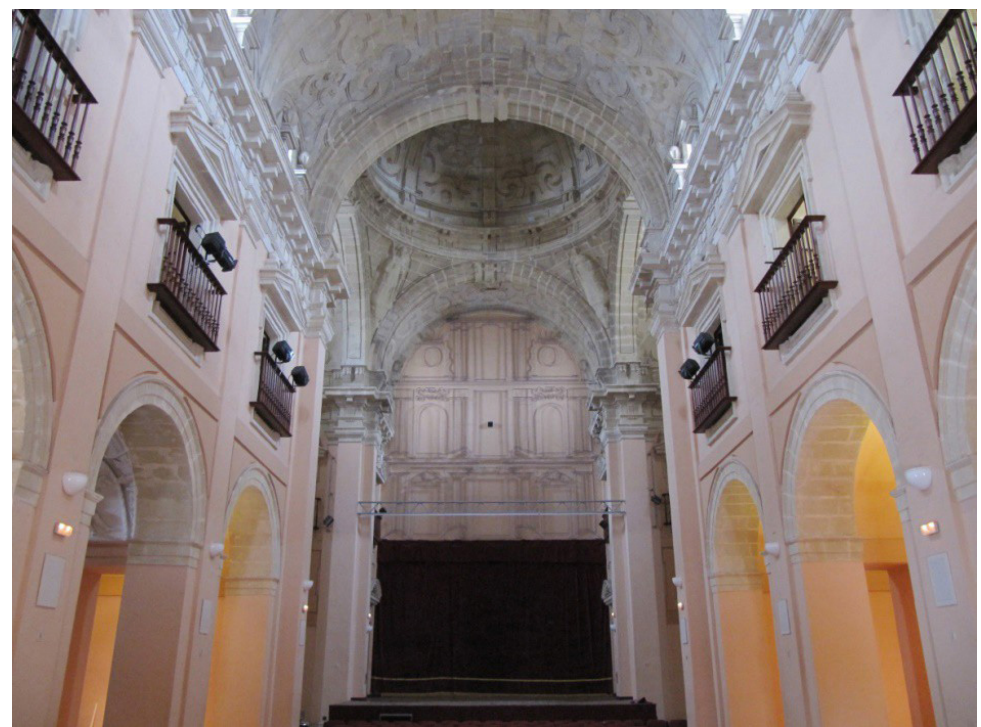

Figura 6. Iglesia del convento de la Merced, de Sanlúcar de Barrameda. Alonso de Vandelvira y Juan de Oviedo de la Bandera, 1616-1624. Fiesta de consagración el 12 de enero de 1625.

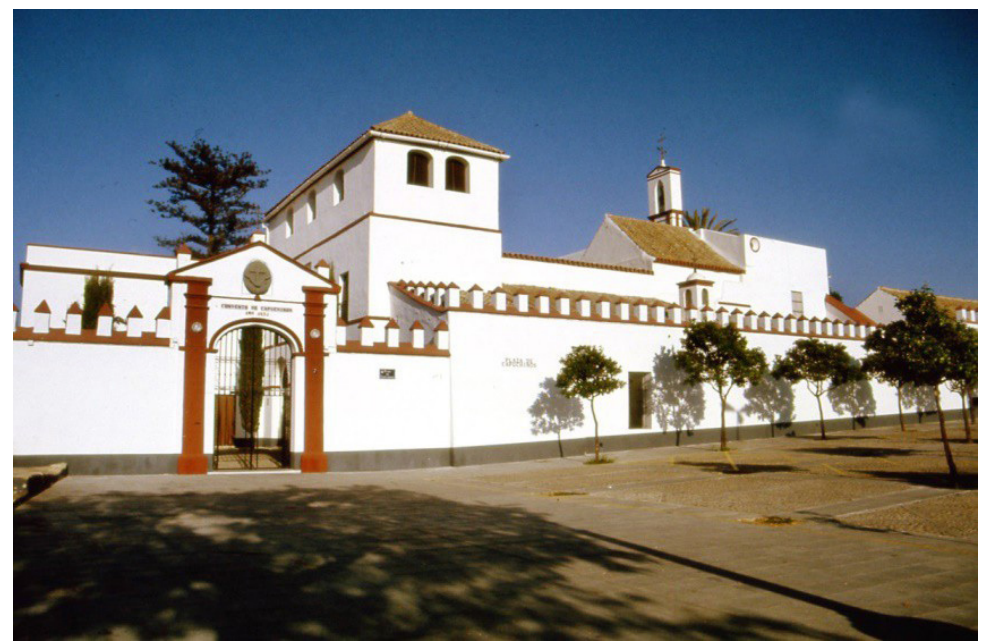

Figura 7. Convento de capuchinos de Ntra. Sra. del Buen Viaje y San Antonio de Padua, de Sanlúcar de Barrameda. Martín Rodríguez de Castro, 1634. Fiesta de consagración el 9 de enero de 1635. 